\title{
Antimalarials and the fight against malaria in Brazil
}

\author{
Luiz MA Carmargo' \\ Saulo de Oliveira ${ }^{2}$ \\ Sergio Basano ${ }^{3}$ \\ Célia RS Garcia ${ }^{2}$ \\ 'ICBV-USP, Monte Negro, Rondônia, \\ Brasil; ${ }^{2}$ Departamento de Fisiologia, \\ Instituto de Biociências, Universidade \\ de São Paulo, SP, Brazil; ${ }^{3}$ CEMETRON, \\ Porto Velho, Guaporé, Brazil
}

Correspondence: Célia RS Garcia Departamento de Fisiologia, Instituto de Biociências, Universidade de

São Paulo, SP, Brazil

Email cgarcia@usp.br

\begin{abstract}
Malaria, known as the "fevers," has been treated for over three thousand years in China with extracts of plants of the genus Artemisia (including Artemisia annua, A. opiacea, and $A$. lancea) from which the active compound is artemisin, a sesquiterpene that is highly effective in the treatment of the disease, especially against young forms of the parasite. South American Indians in the seventeenth century already used an extract of the bark of chinchona tree, commonly named "Jesuits' powder." Its active compound was isolated in 1820 and its use spread all over the world being used as a prophylactic drug during the construction of the Madeira-Mamore railroad in the beginning of the twentieth century. During the 1920 s to the 1940s, new antimalarial drugs were synthesized to increase the arsenal against this parasite. However, the parasite has presented systematic resistence to conventional antimalarial drugs, driving researchers to find new strategies to treat the disease. In the present review we discuss how Brazil treats Plasmodium-infected patients.
\end{abstract}

Keywords: Plasmodium falciparum, malaria, antimalarials, calcium

\section{Introduction}

Malaria is one of the worst health problems in this decade according to the World Health Organization (WHO). Globally, the disease takes the heavy toll of more than one million lives every year. Most of the victims are under the age of five. These astonishing numbers show that one infant dies of malaria every 30 seconds. In the face of this dramatic situation, malaria still continues to receive insufficient attention, due to the fact that the disease mainly affects tropical and subtropical regions of the world rather than temperate zones where industrial and financial power are concentrated. For this reason, malaria is considered a neglected disease.

Considering the pharmaceutical treatment of malaria, we encounter several difficulties. Since the first antimalarial drug synthesis, advances in the comprehension of its mode of action and in the development of new effective antimalarials have been disappointing. The need for low-cost drugs, problems of drug toxicity, and the spread of antimalairal drug resistance in the parasite combine to create a very disturbing scenario for malaria management.

Improving malaria treatment is, more than ever, an issue of great importance. Despite increasing investments in measures against the disease, this problem still needs highly skilled approaches to provide effective prevention and treatment of the disease. $^{1}$

\section{Antimalarials}

The first historical record of a compound with antimalarial properties dates back to 1638 , when the physician Juan de la Vega administered quina, the bark of a tree native to tropical South America now known as cinchona, to the wife of the Viceroy of Peru, treating her illness effectively. ${ }^{2}$ In 1820 quinine was discovered to be the active compound of quina's antimalarial properties. For a long time, quinine was the only antimalarial drug available, and its economic importance rose substantially in 
Table I Classification of blood schizonticidal drugs and their mechanism of action

\begin{tabular}{lll}
\hline Group & Drug & Metabolic target \\
\hline 4-Aminoquinolines & Chloroquine & Hemoglobin digestion by the parasite \\
Methanolquinolines & Amodiaquine & Hemoglobin digestion by the parasite \\
& Quinine & \\
Artemisinin family & Mefloquine & Protein metabolism \\
Artemisinin family & Arofantrine & Protein metabolism \\
Artemisinin family & Artemesinin (qinghaosu) & Protein metabolism \\
Tetracyclines & Artemether & Protein synthesis \\
Lincosamide antibiotic & Tetracycline & Protein synthesis protein synthesis \\
\hline
\end{tabular}

the 19 th century. Many attempts to synthesize the compound were unsuccessful, until an efficient synthesis method was described in 1944. Although quinine has been widely used for centuries, it has high toxicity and needs to be administered several times a day due to its short pharmacological half-life. ${ }^{3}$ Hence, efforts were mobilized to find suitable substitutes for quinine. In 1891, Guttman and Ehrlich were the first to report the antimalarial properties of a synthetic compound when they observed the successful treatment of two patients, using the dye methylene blue. ${ }^{4}$

Much later, in 1932, the synthesis of the first antimalarial, pamaquine, was achieved, ${ }^{5}$ followed by the synthesis of atebrin (quinacrine), an 8-aminoquinoline derivative, with antimalarial properties. ${ }^{6}$

However, due to the high toxicity of these 8-aminoquinolines, new efforts were made in 1940s to find alternatives, leading to the discovery and synthesis of new antimalarials. The new drugs included proguanil, the first antifolate used to treat malaria, and the two 4-aminoquinolines resochin (later renamed chloroquine) and sontaquine, as well as quinine, as already mentioned. ${ }^{7}$ Chloroquine rapidly gained popularity

Table 2 First choice scheme, recommended in the three day treatment of Plasmodium falciparum infections with artemether + lumefantrine $\left(\right.$ Coartem $\left.^{\circledR}\right)$

\begin{tabular}{lll}
\hline Weight & Age & Dosage for three days \\
\hline $5-14 \mathrm{~kg}$ & 6 months to 2 years & I tablet I2//2 hours \\
$15-24 \mathrm{~kg}$ & 3 to 8 years & 2 tablets I2/12 hours \\
$25-34 \mathrm{~kg}$ & 9 to I4 years & 3 tablets I2/12 hours \\
$>35 \mathrm{~kg}$ & $>14$ years & 4 tablets I2/12 hours \\
\hline
\end{tabular}

Notes: Each Coartem ${ }^{\circledast}$ blister has an individual dosage for the treatment of one person. Coartem ${ }^{\circledR}$ comes in four types of packaging, to match patient weight and age. On the first day, the second dose can be administered at intervals of 8 to 12 hours. due to its high efficiency, low toxicity, cheap production cost and high availability. ${ }^{8}$ Unfortunately, improper usage in a single-drug regimen during the 1950s and 1960s led to the emergence of chloroquine-resistant parasites. ${ }^{9}$

During the last few decades, only a small number of new antimalarials have been made available as suitable drugs to treat and control malaria effectively, although during the period 1975-1999 almost 1400 new drugs were registered worldwide. ${ }^{10}$ This new generation included the 4-quinoline-methanol, mefloquine, ${ }^{11}$ the 9 -phenanthrenemethanol, halofantrine, ${ }^{12}$ the 8 -aminoquinoline, primaquine, the 2-hydroxinaphthoquinone, atovaquone (discovered in the early 1940s, but only licensed in 1997), ${ }^{13}$ the artemisin-based compounds such as artesunate and the antifolates such as sulfadoxine and pyrimethamine.

Most of the antimalarials available nowadays fall into three classes: the quinolines, the artemesin-based antimalarials, and the antifolates. However, drug resistance to these compounds is spreading rapidly and we face a situation where, in some cases, almost no completely effective drug can be found to treat malaria. ${ }^{14}$

The discovery and development of new effective antimalarial drugs are now issues of great importance. Rather than focusing investment in the traditional mass-screening of chemicals for antimalarial action, the aim needs to turn to increase the understanding of how available antimalarials

Table 3 Second choice scheme, recommended in the three day treatment of Plasmodium falciparum infections

\begin{tabular}{ll}
\hline Drug & Dosage \\
\hline Artesunate $600 \mathrm{mg}$ plus & I tablet daily for 3 days \\
Mefloquine $250 \mathrm{mg}$ & 6 tablets I unique dose $(\mathrm{I}, 5 \mathrm{~g})$ \\
\hline
\end{tabular}


Table 4 Recommended scheme for the treatment of Plasmodium falciparum infections with quinine for three days plus doxicyclin for five days and primaquine on the sixth day

\begin{tabular}{|c|c|c|c|c|}
\hline \multirow[t]{3}{*}{ Drugs and dosage ages } & \multicolumn{2}{|c|}{ Ist, 2nd, and 3rd day } & \multirow{3}{*}{$\begin{array}{l}\text { 4th and 5th day } \\
\text { Doxicycline } \\
100 \mathrm{mg}\end{array}$} & \multirow{3}{*}{$\begin{array}{l}\text { 6th day } \\
\text { Primaquine } \\
15 \mathrm{mg}\end{array}$} \\
\hline & Quinine & Doxicycline & & \\
\hline & $500 \mathrm{mg}$ & $100 \mathrm{mg}$ & & \\
\hline 8 to 11 years & I and $1 / 2$ tablet & I tablet & I tablet & I tablet \\
\hline 12 to 14 years & $21 / 2$ tablets & $11 / 2$ tablet & $11 / 2$ tablet & 2 tablets \\
\hline 15 years or more & 4 tablets & 2 tablets & 2 tablets & 3 tablets \\
\hline
\end{tabular}

Notes: Quinine and doxicycline should be administered twice a day, each 12 hours, doxiciclyne and primaquine should not be administered to pregnant women, and primaquine is administered in order to eliminate $P$. falciparum gametocytes.

work at the molecular level in order to provide a sound rationale for the design of new and better drugs.

\section{Antimalarial action}

For the most exploited group of antimalarials, the quinolines, little is known about how precisely they work, although there are many hypotheses. The first fact that needs to be highlighted is that some quinolines, particularly chloroquine, tend to accumulate in the parasite's digestive vacuole (food vacuole), suggesting that this acidic compartment might be their main site of action. An interesting model has been proposed to explain this unusual accumulation, based on the known behavior of such weak diprotic bases. It is possible that, after entering the parasite, these quinolines become trapped inside the digestive vacuole where in its acid environment they gain an extra proton to add to their original monoprotonated state. With this additional proton, the quinolines are unable to pass back through the enclosing membrane of the digestive vacuole.

The observed accumulation of quinolines in the digestive vacuole prompted further work on their mode of action, which led to the discovery of another very peculiar effect, their inhibition of the synthesis of the hemozoin pigment by the parasite. ${ }^{15}$ This pigment is formed in the digestive vacuole as a result of the parasite's feeding on the hemoglobin within the red blood cell it inhabits.
The digestion of hemoglobin is catalyzed in the digestive vacuole by several proteolytic enzymes including plasmepsins I, II, and IV, histoaspartic protease (HAP), falcipain 2, falcipain 3 , and falcilysin. ${ }^{15}$ Beside the aminoacids generated from the degradation of the protein component of hemoglobin, toxic intermediates derived from the heme group are also produced, but these are rapidly converted by the parasite into the nontoxic crystalline brown pigment, hemozoin. This detoxification process entails first the oxidation of the heme product ferrous protoporphyrin IX, into ferric protoporphyrin IX, also called hematin.

Ferric protoporphyrin IX then aggregates by a nonenzymatic process into crystals of hemozoin. The process of crystallization is not fully understood and may require parasite-derived molecules to initiate. It is hypothetized that quinolines inhibit this process, causing a toxic accumulation which is fatal to the parasite. However, some data suggest that a strong inhibition of hemozoin synthesis is not necessarily correlated with a higher antimalarial activity, which weakens the hemozoin inhibition hypothesis. Another interesting effect caused by quinolines, in particular by chloroquine, is the mobilization of $\mathrm{Ca}^{2+}$ from compartments within the parasite. ${ }^{16,17}$ Since this second messenger is exploited by the parasite to modulate its own life cycle and several other cellular functions, ${ }^{18-21}$ it would not be surprising that a disruption in Plasmodium $\mathrm{Ca}^{2+}$

Table 5 Recommended scheme for the treatment of Plasmodium falciparum infections with quinine for three days plus clindamycin for five days, in pregnant women or children less than eight years old or contraindication to the use of tetracyclin

\begin{tabular}{|c|c|c|c|}
\hline \multirow[t]{2}{*}{ Drugs and dosage age } & \multicolumn{2}{|l|}{ I st, 2nd, and 3rd day } & \multirow{2}{*}{$\begin{array}{l}\text { 4th and 5th day } \\
\text { Clindamycin }\end{array}$} \\
\hline & Quinine & Clindamycin & \\
\hline$<8$ years & $30 \mathrm{mg} / \mathrm{kg} /$ day each 8 hours & $20 \mathrm{mg} / \mathrm{kg} /$ day each 12 hours & $20 \mathrm{mg} / \mathrm{kg} /$ day each 12 hours \\
\hline 8 to 11 years & $11 / 2$ tablets & $20 \mathrm{mg} / \mathrm{kg} /$ day each 12 hours & $20 \mathrm{mg} / \mathrm{kg} /$ day each 12 hours \\
\hline 12 to 14 years & $21 / 2$ tablets & $20 \mathrm{mg} / \mathrm{kg} /$ day each 12 hours & $20 \mathrm{mg} / \mathrm{kg} /$ day each 12 hours \\
\hline 15 years or more & 4 tablets & $20 \mathrm{mg} / \mathrm{kg} /$ day each 12 hours & $20 \mathrm{mg} / \mathrm{kg} /$ day each 12 hours \\
\hline
\end{tabular}

Note: The dosage of quinine must be given each 12 hours (each tablet is $500 \mathrm{mg}$ ). 
Table 6 Recommended scheme for severe malaria due to P. falciparum

\begin{tabular}{l} 
Drugs \\
\hline I. First choice \\
A. Artemesinin derivates \\
Intravenous artesunate: $2.4 \mathrm{mg} / \mathrm{kg}$ as "attack dose" \\
and $1.2 \mathrm{mg} / \mathrm{kg}$ after 4,24 , and 48 hours. Each dose should be \\
diluted in $500 \mathrm{~mL}$ of isotonic solution (preferably $5 \%$ or $10 \%$ \\
glucose), infused in one hour. \\
B. Intramuscular artemether \\
Injected at $4 \mathrm{mg} / \mathrm{kg}$ one dose in the first day. After 24 hours, \\
inject $2 \mathrm{mg} / \mathrm{kg}$ each 24 hours for \\
4 days in one dose for a total of 5 days of treatment. \\
2 . Second choice \\
A. Intravenous quinine (quinine dichloride) \\
Infusion of $20-30 \mathrm{mg} / \mathrm{kg} /$ day, diluted in isotonic solution (preferably \\
$5 \%$ or $10 \%$ glucose, maximum of 500 ml) for 4 hours of continuous \\
IV infusion, divided in three doses a day ( $8 / 8$ hours). \\
B. Intravenous quinine associated with intravenous clindamycin \\
Quinine dosage should be used as described above for 3 days. \\
Concomitantly, clindamycin, $20 \mathrm{mg} / \mathrm{kg}$ should be administered in \\
two doses each I 2 hours, diluted in a $5 \%$ or $10 \%$ glucose infusion \\
solution ( $15 \mathrm{ml} / \mathrm{kg}$ ), dripping slowly, in one hour for 7 days. \\
\hline
\end{tabular}

Important observations

The treatment should be complemented with clindamycin, $20 \mathrm{mg} / \mathrm{kg}$ each 12 hours for 5 days; or with doxicycline $3.3 \mathrm{mg} / \mathrm{kg}$ divided in two doses each 12 hours for 5 days; or mefloquine $15-20 \mathrm{mg} / \mathrm{kg}$ in one unique dose. These drugs should be administered at the end of the treatment with artemisinin derivates. Doxacycline should not be administered to pregnant women and children less than eight years old. Mefloquine should not be administered to women in the first trimester of pregnancy.

Notes: Artemisin derivates have proven to be very effective and rapidly reduce or eliminate parasites. Therefore, it is necessary that these medications are protected from their abusive use and indicated only for serious and complicated cases. The preferential specific therapeutic scheme for pregnant women is the association of quinine and intravenous clindamycin due to its effectiveness and because it causes no harm either to the mother or to the child.

homeostasis leads eventually to parasite death. Several studies on Plasmodium $\mathrm{Ca}^{2+}$ signaling and homeostasis have been published, ${ }^{18-27}$ showing the crucial role of this ion in the parasite life cycle.

The remaining class of antimalarials, the artemisinrelated compounds, are thought to act by cleaving peroxide bridges, thus generating toxic free radicals. This cleaving could be related to the high efficiency of artemisinin action, and the food vacuole is a possible target. ${ }^{28}$

In the past twenty years, the Brazilian Ministry of Health, together with the Fundação Nacional da Saúde (National Health Foundation) aided by a committee of specialists, has periodically updated malaria therapeutics in the country, taking into consideration personal experiences or experiences based on evidence that is more suitable to Brazilian reality. ${ }^{29,30}$ Generally speaking, the traditional antimalarial chemical entities remain as the main drugs (Table 1) with the association of two drugs, generally differing in their capacity/speed of cleaning of blood-stage parasites in order to avoid the appearing of drug-resistant falciparum malaria. The classical association of chloroquine and primaquine was maintained for malaria vivax treatment, with some alterations or recommendations regarding the dosage..$^{29,30}$

In 2007 and 2008, the Ministry of Health introduced new associations: artemisine and lumefantrine $\left(\right.$ Coartem $\left.^{\circledR}\right)$ (Table 2) and artesunate with mefloquine (Artequin ${ }^{\circledR}$ ) (Table 3).

Table 7 Alternative scheme for the treatment of Plasmodium falciparum infections in children, with artesunate suppository capsules in four days, with the administration of one dose of mefloquine in the third day

\begin{tabular}{|c|c|c|c|c|c|}
\hline \multirow[t]{2}{*}{ Drugs and dosage age } & \multirow{2}{*}{$\begin{array}{l}\text { Ist and 2nd day } \\
\text { Artesunate } \\
\text { suppository } \\
\text { capsule }\end{array}$} & \multicolumn{2}{|l|}{$3 r d$} & \multirow{2}{*}{$\begin{array}{l}\text { 4th } \\
\text { Artesunate } \\
\text { suppository } \\
\text { capsule }\end{array}$} & \multirow{2}{*}{$\begin{array}{l}\text { 5th } \\
\text { Primaquine } \\
15 \mathrm{mg}\end{array}$} \\
\hline & & $\begin{array}{l}\text { Artesunate } \\
\text { suppository } \\
\text { capsule }\end{array}$ & $\begin{array}{l}\text { Mefloquine } \\
\text { tablet }\end{array}$ & & \\
\hline I to 2 years & 1 & 1 & $1 / 2$ & 1 & $1 / 2$ \\
\hline 3 to 5 years & $2(\mathrm{~A})$ & $2(\mathrm{~A})$ & I & I & I \\
\hline 6 to 9 years & $3(B)$ & $3(B)$ & $11 / 2$ & 1 & $11 / 2$ \\
\hline 10 to 12 years & $3(\mathrm{~B})$ & $3(\mathrm{~B})$ & $21 / 2$ & $3(\mathrm{~B})$ & 2 \\
\hline
\end{tabular}

Abbreviations: A, Administration of one suppository capsule each 12 hours; B, Administration of one suppository capsule each 8 hours.

Notes: Suppository capsules may be stored at room temperature; Mefloquine may be administered in a $15-20 \mathrm{mg} / \mathrm{kg}$ dose, twice a day, each 12 hours. This scheme is not applicable in diarrheic children. 
Table 8 Quinine 7-day monotherapy in children

Drugs and dosage age

Quinine $500 \mathrm{mg}$ tablet

(Daily dose for 7 days)

\begin{tabular}{ll}
\hline Less than 6 months & $1 / 4$ \\
6 to I I months & $1 / 2$ \\
I to 2 years & $3 / 4$ \\
3 to 6 years & I \\
7 to II years & $11 / 2$ \\
I 2 to I4 years & 2 \\
$>$ I4 years & 3
\end{tabular}

According to handbooks, therapeutic schemes may be divided according to parasite specimen and case seriousness with special attention to special categories such as children or special situations such as allergies, intolerance, or contraindication. ${ }^{29,30}$ For small children, smash the tablet to make the administration easier, and have them swallow it with water or milk. It is recommended that children take the tablet with food. Do not administer the drug to pregnant women in their first trimester of pregnancy nor to children less then six months of age.

\section{P. falciparum malaria}

Among the four forms of malaria, the disease caused by P. falciparum brings is the one that brings more concern to physicians, due to its high pathogenicity and resistance to drugs. ${ }^{910-14}$ Nowadays, in the Amazonian rural areas, the combination of quinine and antibiotics is still widely used (Table 4), although the tertiary and secondary centers of reference (large hospitals in specialized centers), generally choose to use Coartem ${ }^{\circledR}$. However, in areas outside the
Amazonian region, the use of the classical association quinine and tetracycline derivates is preconized, especially doxicycline and the use of clindamycin (when there is restriction to the use of doxicycline) (Table 5). We should emphasize that the use of artemisinin derivates of parenteral formulation is restricted to the serious malaria cases according to the Ministry of Health guidelines ${ }^{29,30}$ (Table 6), and that alternative rectal administration is also of value when the use of oral treatment or parenteral administration is impossible (Table 7). Although the use of mefloquin in the treatment of P. falciparum malaria does not present signs of significant resistance in Brazil, ${ }^{31}$ its use in monotherapy or associated to primaquine has been prohibited in the endemic areas by the present committee.

It is worth remembering that the association with only one dose of primaquine should be present when using quinine monotherapy or in combination to destroy the sexual forms.

As presented above, the character of malaria treatment in Brazil varies, according to the studied area. In some areas the use of quinine in monotherapy in pregnant women is still used in a seven day scheme (Table 8).

\section{P. vivax malaria}

Vivax malaria, less virulent than P. falciparum malaria, is the most common form of the disease in Brazil. ${ }^{29,30}$ Although the classical association of chloroquine with primaquine (Table 9) for vivax malaria treatment has not changed in the past 20 years, chloroquine infusions were abolished due to operational problems. Therefore, in some cases intravenous medications for $P$. falciparum malaria are applied to treat vivax malaria. Nowadays, there is a tendency

Table 9 Scheme recommended for Plasmodium vivax infections with chloroquine (3 days) and primaquine (7 days)

\begin{tabular}{|c|c|c|c|c|c|c|c|c|}
\hline \multirow[t]{3}{*}{$\begin{array}{l}\text { Drugs and } \\
\text { dosage age }\end{array}$} & \multicolumn{3}{|l|}{ Ist day } & \multicolumn{3}{|c|}{ 2nd and 3 rd day } & \multirow{2}{*}{\multicolumn{2}{|c|}{$\begin{array}{l}\text { 4th, 5th, 6th, } \\
\text { and 7th day } \\
\begin{array}{l}\text { Primaquine } \\
\text { tablet }\end{array}\end{array}$}} \\
\hline & \multirow[t]{2}{*}{$\begin{array}{l}\text { Chloroquine } \\
\text { tablet }\end{array}$} & \multicolumn{2}{|c|}{$\begin{array}{l}\text { Primaquine } \\
\text { tablet }\end{array}$} & \multirow[t]{2}{*}{$\begin{array}{l}\text { Chloroquine } \\
\text { tablet }\end{array}$} & \multicolumn{2}{|c|}{$\begin{array}{l}\text { Primaquine } \\
\text { tablet }\end{array}$} & & \\
\hline & & Adult & Child & & Adult & Child & Adult & Child \\
\hline Less than 6 months & $1 / 4$ & - & - & $1 / 4$ & - & - & - & - \\
\hline 6 to 11 months & $1 / 2$ & - & I & $1 / 2$ & - & I & - & 1 \\
\hline I to 2 years & 1 & - & I & $1 / 2$ & - & I & - & 1 \\
\hline 3 to 6 years & I & - & 2 & 1 & - & 2 & - & 2 \\
\hline 7 to II years & 2 & 1 & 1 & $11 / 2$ & I & I & 1 & I \\
\hline 12 to 14 years & 3 & $11 / 2$ & - & 2 & $11 / 2$ & - & $11 / 2$ & - \\
\hline$>15$ years & 4 & 2 & - & 3 & 2 & - & 2 & - \\
\hline
\end{tabular}

Notes: Primaquine:Adult $15 \mathrm{mg}$ tablets and child $5 \mathrm{mg}$ tablets. Chloroquine and primaquine should be taken with small meals, preferably. Do not administer primaquine to pregnant women and children less than six months of age. 
Table 10 Scheme for the prevention of recurrence of Plasmodium vivax malaria, with one weekly dose of chloroquine for three months

\begin{tabular}{lll}
\hline Weight (kg) & Age & $\begin{array}{l}\text { Number of tablets } \\
(150 \mathrm{mg}) \text { per week }\end{array}$ \\
\hline $5-6$ & $<4$ months & $1 / 4$ \\
$7-10$ & $4-11$ months & $1 / 2$ \\
$11-14$ & $1-2$ years & $1 / 2$ \\
$15-18$ & $3-4$ years & $3 / 4$ \\
$19-24$ & $5-7$ years & 1 \\
$25-35$ & $8-10$ years & 1 \\
$36-50$ & $11-13$ years & 2 \\
$>50$ & $>14$ years & 2 \\
\hline
\end{tabular}

Notes: This scheme is recommended to patients who suffered malaria recurrences after correct treatment and/or to pregnant women and children less than six months of age who cannot receive primaquine.

to maintain $1.5 \mathrm{~g}$ of chloroquine and adequate primaquine doses for patients weighing more than $70 \mathrm{~kg}$. In case of malaria recurrence, a $50 \%$ to $100 \%$ increase in the initial dose of primaquine is recommended. In cases in which primaquine cannot be used (pregnant women, children less than six months old, persons who are deficient in glucose 6-phosphate dehydrogenase enzyme, allergic persons, etc.), exclusive chloroquine therapy may be given ${ }^{29,30}$ as mentioned in Table 10 .

\section{Malaria caused by other plasmodium species}

Treatment of malaria caused by $P$. ovale is performed with the same protocols used for vivax malaria. Malaria caused by P. malariae, although the less frequently diagnosed in Brazil,

Table II Alternative scheme for the treatment of Plasmodium vivax infections in vomiting children, with artesunate suppository capsules (4 days), and primaquine ( 7 days)

\begin{tabular}{|c|c|c|c|c|}
\hline \multirow[t]{3}{*}{$\begin{array}{l}\text { Drugs and } \\
\text { dosage age }\end{array}$} & \multirow{3}{*}{$\begin{array}{l}\text { Ist, } 2 \text { nd, } \\
\text { and } 3 \text { rd day } \\
\text { Artesunate } \\
\text { suppository } \\
\text { capsules }\end{array}$} & \multirow{3}{*}{$\begin{array}{l}\text { 4th day } \\
\text { Artesunate } \\
\text { suppository } \\
\text { capsules }\end{array}$} & \multirow{2}{*}{\multicolumn{2}{|c|}{$\begin{array}{l}\text { 5th to } \\
\text { I I th day } \\
\text { Primaquine } \\
\text { tablets }\end{array}$}} \\
\hline & & & & \\
\hline & & & $5 \mathrm{mg}$ & $15 \mathrm{mg}$ \\
\hline I to 2 years & 1 & I & I & \\
\hline 3 to 5 years & $2(\mathrm{~A})$ & I & & $1 / 2$ \\
\hline 6 to 9 years & $3(B)$ & 1 & 2 & \\
\hline 10 to 12 years & $3(\mathrm{~B})$ & $3(\mathrm{~B})$ & & 1 \\
\hline
\end{tabular}

Abbreviations: A, One suppository capsule should be administered each 12 hours; B, One suppository capsule should be administered each 8 hours; C, For children less than one year old and children older than 12 years, see Table 10.

Notes: $50 \mathrm{mg}$ suppository capsules may be kept at room temperature. Adult and child should have $5 \mathrm{mg}$ and $15 \mathrm{mg}$ primaquine, respectively. Primaquine dose $(0,50 \mathrm{mg} / \mathrm{kg})$ preferably should be taken at meals. should be treated as malaria $P$. vivax (Table 10), except for the use of primaquine, since this parasite does not present hypnozoitic forms.

\section{Conclusion}

Malaria parasites have a complex life cycle. The struggle against the disease - not only in Brazil but in the whole world - is now facing a huge obstacle: the increasing appearance of parasites resistant to the classical antimalarials. Funding incentives in the area of neglected diseases have been the focus of Brazilian funding agencies, thus supporting work on several aspects such as epidemiology, system biology, immunology, and others. The multidisciplinary work is a necessity to help us to understand better this pathogen's tricks and to achieve new forms, tools, and strategies to continue the battle against this disease.

\section{Acknowledgments}

Luiz MA Camargo, Saulo de Oliveira and Sergio Basano contributed equally to this review. We thank Fundação de Amparo à Pesquisa de São Paulo (Fapesp) and MS-CNPq Neglected Tropical Disease grant for funding CRSG. SL received fellowship from CNPq-PIBIC. We thank Drs Lawrence Bannister and Marisis Camargo for critically reading the manuscript. The authors report no conflicts of interest in this work.

\section{References}

1. Hsu E. The history of qing hao in the Chinese materia medica. Trans R Soc Trop Med Hyg. 2006;100(6):505-508.

2. Goldring JD, Padayachee T, Ismail I. Plasmodium falciparum malaria: rosettes are disrupted by quinine, artemisinin, mefloquine, primaquine, pyrimethamine, chloroquine and proguanil. Mem Inst Oswaldo Cruz. 1999;94(5):667-674.

3. Camargo EP. Rev. Inst. Estudos avançados USP, São-Paulo-Brasil. 2005;9(24):211-227.

4. Malária. Superintendência de Controle de Endemias. c2000-2001 [cited 2008 Jun 18]. Available from: http://www.sucen.sp.gov.br/doencas/ malaria/texto_malaria.htm.

5. Bruce-Chwatt LJ. History of malaria from pre-history into erradication. In: Wernsdorfer WH, McGregor I, editors. Malaria: principles and practice of malariology. Edinburgh, UK: Churchill-Livingstone; 1988.

6. Bruce-Chewatt LJ. Alphonses Laveran's discovery 100 years ago and todays's global fight against malaria. J Royal Soc Med. 1981;74: 531-536.

7. Krogstad DJ. Malaria as a reemerging disease. Epidemiol Rev. 1996; 18(1):77-89.

8. Hill DR, Baird JK, Parise ME, Lewis LS, Ryan ET, Magill AJ. Primaquine: report from $\mathrm{CDC}$ expert meeting on malaria chemoprophylaxis. Am J Trop Med Hyg. 2006;75(3):402-415.

9. Ringwald P. Current antimalarial drugs: resistance and new strategies. Bull Acad Natl Med. 2007;191(7):1273-1284;

10. Wongsrichanalai C, Meshnick SR. Declining artesunate-mefloquine efficacy against falciparum malaria on the Cambodia-Thailand border. Emerg Infect Dis. 2008;14(5):716-719. 
11. Klein EY, Smith DL, Boni MF, Laxminarayan R. Clinically immune hosts as a refuge for drug-sensitive malaria parasites. Malar J. 2008;7:67.

12. Rose GW, Suh KN, Kain KC, Le Saux N, McCarthy AE. Atovaquone-proguanil resistance in imported falciparum malaria in a young child. Pediatr Infect Dis J. 2008;27(6):567-569.

13. Ibrahim ML, Hassane H, Konate L, Adamou S, Ousmane I, Adehossi E, Jeanne I, Duchemin JB. [Plasmodium falciparum chloroquine and pyrimethamine resistance monitoring network with molecular tools in the Niger river valley, Republic of Niger.] Bull Soc Pathol Exot. 2008;101(1):47-49.

14. A malária no Brasil. Portal da Saúde, Ministério da Saúde. 2005 Jan [cited 2008 Jun 18]. Available from: http://portal.saude.gov.br/portal/ arquivos/pdf/be_malaria_01_2005.pdf.

15. Drew ME, Banerjee R, Uffman EW, Gilbertson S, Rosenthal PJ, Goldberg DE. Plasmodium food vacuole plasmepsins are activated by falcipains. J Biol Chem. 2008;283(19):12870-12876.

16. Passos AP, Garcia CRS. Inositol 1,4,5 trisphosphate induced $\mathrm{Ca}^{2+}$ release from chloroquine - sensitive and insensitive intracellular stores in the intraerythrocytic stage of the malaria parasite P. chabaudi. Biochem Biophys Res Commun. 1998;245:155-160.

17. Gazarini ML, Sígolo CA, Markus RP, Thomas AP, Garcia CRS. Antimalarial drugs disrupt íon homeostasis in malarial parasites. $\mathrm{Mem}$ Inst Oswaldo Cruz. 2007;102(3):329-334,

18. Garcia CRS. Calcium signaling in the blood stage malaria parasite. Parasitol Today. 1999;15:488-491.

19. Beraldo FH, Garcia CRS. Products of triptophan catabolism can induce $\mathrm{Ca}^{2+}$ release and modulate the cell cycle of $P$. falciparum malaria parasite. J Pineal Res. 2005;39(3):224-230.

20. Beraldo FH, Almeida FM, da Silva AM, Garcia CRS. Cyclic AMP and calcium interplay as second messengers in melatonin dependent regulation of Plasmodium falciparum cell-cycle. J Cell Biol. 2005;170(4):551.

21. Hotta CT, Gazarini ML, Beraldo FH, et al. Calcium-dependent modulation by melatonin of the circadian rhythms in malaria parasites. Nature Cell Biol. 2000;2:466-468.
22. Passos AP, Garcia CRS. Characterization of $\mathrm{Ca}^{2+}$ transport activity associated with a non-mitochondrial calcium pool in the rodent malaria parasite P. chabaudi. Biochem Mol Biol Int. 1997;42:919-925.

23. Varotti F, Beraldo FH, Gazarini M, Garcia CRS. Plasmodium falciparum parasites display a thapsigargin-sensitive $\mathrm{Ca}^{2+}$ pool. Cell Calcium. 2003;33:137-144.

24. Gazarini M, Thomas A, Pozzan T, Garcia CRS. Survival in a low calcium environment: How intracellular parasites such as Plasmodia have solved the problem. J Cell Biol. 2003;161:103-110.

25. Gazarini ML, Garcia CRS. The malaria parasite mitochondrion senses cytosolic $\mathrm{Ca}^{2+}$ fluctuations. Biochem Biophys Res Commun. 2004;321:134-138.

26. Beraldo FH, Mikoshiba K, Garcia CRS. 2-Aminoethyl diphenylborinate blocks the signal transduction pathway of melatonin action on the human malaria parasite Plasmodium falciparum cell cycle. J Pineal Res. 2007;43(4):360-364.

27. Garcia CRS, Azevedo MF, Wunderlich G, Budu A, Young J, Bannister L. Plasmodium in the post genome era: New insights into the molecular cell biology of the malaria parasites. Int Rev Mol Cell Biol. 2008;266: 85-156.

28. del Pilar Crespo M, Avery TD, Hanssen E, et al. Artemisinin and a series of novel endoperoxide antimalarials exert early effects on digestive vacuole morphology. Antimicrob Agents Chemother. 2008;52(1): 98-109.

29. Ministério da Saúde do Brasil. Fundação Nacional de Saúde. Manual de terapêutica da Malária. Ministério da Saúde do Brasil; 1990. p. 110

30. Ministério da Saúde do Brasil. Fundação Nacional de Saúde. Manual de terapêutica da Malária. Ministério da Saúde do Brasil; 2001. p. 102.

31. Camargo LMA, Basano SA, Bianco A, Tylor MRJ. An in vivo assay do assess mefloqine $25 \mathrm{mg} / \mathrm{kg}$ in the treatment of uncomplicated falciparum malaria in Rondonia, Brazil. Braz J Infect Dis. 2006;10:279-282. 
